\title{
Using DNA Metabarcoding to Identify Floral Visitation by Pollinators
}

\author{
Abigail Lowe ${ }^{1,2 *}$, Laura Jones ${ }^{1}$, Lucy Witter ${ }^{1,3}$, Simon Creer $^{2}$, and Natasha de Vere ${ }^{4}$ \\ 1 National Botanic Garden of Wales, Llanarthne, SA32 8HG, UK; abigail.lowe@gardenofwales.org.uk, \\ laura.jones@gardenofwales.org.uk, lucy.witter@gardenofwales.org.uk \\ 2 Molecular Ecology and Evolution Group, School of Natural Sciences, Bangor University, Bangor, UK; \\ s.creer@bangor.ac.uk \\ 3 IBERS, Aberystwyth University, Aberystwyth SY23 3FL, UK \\ 4 Natural History Museum of Denmark, University of Copenhagen, Denmark; natasha.devere@snm.ku.dk \\ * Correspondence: abigail.lowe@gardenofwales.org.uk
}

\begin{abstract}
The identification of floral visitation by pollinators provides an opportunity to improve our understanding of the fine-scale ecological interactions between plants and pollinators, contributing to biodiversity conservation and promoting ecosystem health. In this review we outline the various methods which can be used to identify floral visitation, providing a comparison between molecular and non-molecular methods. We review the literature covering the ways in which DNA metabarcoding has been used to answer ecological questions relating to plant use by pollinators and discuss the findings of this research. We present detailed methodological considerations for each step of the metabarcoding workflow, from sampling through to amplification and finally bioinformatic analysis. Detailed guidance is provided to researchers for utilization of these techniques, emphasizing the importance of standardization of methods and improving the reliability of results. Future opportunities and directions of using molecular methods to analyze plant-pollinator interactions are then discussed.
\end{abstract}

Keywords: DNA metabarcoding; pollen; pollinators; pollen metabarcoding; plant-pollinator interactions; eDNA; DNA barcoding; honeybees; bumblebees; hoverflies

\section{Background}

Understanding the relationship between plants and pollinators is vital for biodiversity conservation, food security, and ecosystem function [1,2]. Worldwide, there are approximately 350,000 animal pollinator species, of which insects contribute a significant proportion [3]. Despite the importance of pollinators, evidence of declines in species richness and abundance are increasing across the globe [4,5]. A global analysis of pollinator decline has found that the most significant drivers of decline are land use change, pesticides, climate change, pests, and pathogens [6].

DNA metabarcoding and related approaches provide powerful tools for investigating pollinator foraging preferences and should be a standard part of the ecologist's toolkit. The aim of this review is to describe the range of approaches and methods available, along with their opportunities and challenges. We thoroughly explore the ecological questions that can be answered from identifying floral visitation across a range of species and habitats and present a summary of findings from the literature. The entire pollen metabarcoding workflow is described along with considerations and guidance for each step, in the hope of inspiring more researchers to adopt these techniques.

Identifying floral visitation can provide an insight into the resources used by insects and the pollination services they deliver. Whilst the methods subsequently described do 
not detect the process of pollination, we use the term pollinators as a general term to refer to flower-visiting insects.

\section{Methods for identifying floral visitation by pollinators}

Floral visitation studies may be plant- or insect- focused. Historically, the diet of pollinators has been studied by observing insects visiting plants. This involves recording which pollinators visit plants, either within established habitats [7-9] or in experimental conditions [10]. Alternatively, insects themselves may be observed and flower visitation tracked by methods such as mark recapture using paint, plastic tags [11] or harmonic radar [12], which requires prior knowledge of the location of floral resources. In honeybees, the location of resources is communicated to the colony using waggle dances [13] which can be de-coded to elucidate forage preferences and behavior [14].

Floral visitation may also be investigated by identifying the pollen collected by the insect. Pollen microscopy has been widely utilized for diet characterization by identifying pollen grains obtained from the bodies of individuals $[15,16]$, honey $[17,18]$ or nest provisions $[19,20]$. However, the identification of pollen grains to species level using light microscopy is difficult and time consuming [21]. In recent years, automated machine learning systems have been developed to identify pollen from images and are showing great promise [22-24].

Alternatively, pollen may be identified by DNA metabarcoding: a process involving identifying all species in an environmental sample using DNA barcode markers and highthroughput sequencing [25-27]. DNA metabarcoding has been used to successfully identify pollen from provisions within nests [28-30], honey [31-33], proboscises [34,35], guts [36,37], and the legs or bodies of insects [38-40] (Supporting Information). Whilst the majority of DNA metabarcoding studies utilize pollen, some have identified raw plant material from within nests to identify the leaf preferences of solitary bees [41-43].

Shotgun metagenomics is an alternative tool which can be used to identify taxonomic diversity within a mixed sample using untargeted sequencing of genomic fragments mapped to whole genomes or barcode regions [44,45]. By mapping genome-skims to a constructed reference library of plastid genomes, Lang et al., [46] demonstrated quantitative identification of $>97 \%$ taxa in mixed pollen samples. The advantages of metagenomic methods are the option of PCR-free processes which reduce possible amplification biases, long read lengths, and increasing taxonomic resolution compared to targeted sequencing of specific regions [44,47]. The main limitation facing whole-genome studies is that currently, few whole plant genomes are available, resulting in difficulties assembling reference material [44]. A further promising approach is the use of reverse metagenomics to map long reads produced by the MinION to genomic skims, a method which has produced semi-quantitative identification of plant species in mixed pollen loads [47].

An example of a more novel approach to elucidating floral visitation is through the method of obtaining residual insect DNA from plants themselves [48]. Similarly, the identification of 'microbial signatures' specific to pollinators within nectar can also be used to elucidate visitation $[49,50]$.

\section{Comparison of molecular methods with non-molecular methods}

Each method of identifying floral visitation has advantages and disadvantages which must be considered (Table 1). Observational methods allow plant-pollinator interactions and networks to be identified and constructed quickly and cheaply, however, as the 
Table 1. Methods of detecting floral visitation by pollinators along with their advantages and disadvantages.

\begin{tabular}{|c|c|c|}
\hline Method & Advantages & Disadvantages \\
\hline $\begin{array}{l}\text { Observations of } \\
\text { plants or } \\
\text { pollinators }\end{array}$ & $\begin{array}{l}\text { Easy to set up and conduct } \\
\text { surveys } \\
\text { - } \quad \text { Cheap } \\
\text { - } \quad \text { The type of resource used can } \\
\text { be identified (e.g., pollen, } \\
\text { nectar, resin) } \\
\text { - Can track individuals using } \\
\text { mark recapture methods }\end{array}$ & $\begin{array}{l}\text { - Some interactions are not observed due to } \\
\text { spatiotemporal restrictions of both plants } \\
\text { and pollinators } \\
\text { - } \quad \text { Sampling effort is labour intensive and has } \\
\text { a direct effect on number of links observed } \\
\text { - Limited by field identification of pollinators } \\
\text { and plants } \\
\text { - Often qualitative data only }\end{array}$ \\
\hline $\begin{array}{l}\text { Waggle dance } \\
\text { analysis }\end{array}$ & $\begin{array}{l}\text { - Can track foraging location of } \\
\text { individuals over short and } \\
\text { long distances }\end{array}$ & $\begin{array}{l}\text { - Only suitable for honeybees } \\
\text { - } \quad \text { Need prior knowledge of location of } \\
\text { resources to infer visitation } \\
\text { - } \quad \text { Landscape-level analysis rather than } \\
\text { specific resource use }\end{array}$ \\
\hline Harmonic radar & $\begin{array}{l}\text { - } \quad \text { Can track insects up to } 700 \mathrm{~m} \\
\text { - } \quad \text { Can track individuals }\end{array}$ & 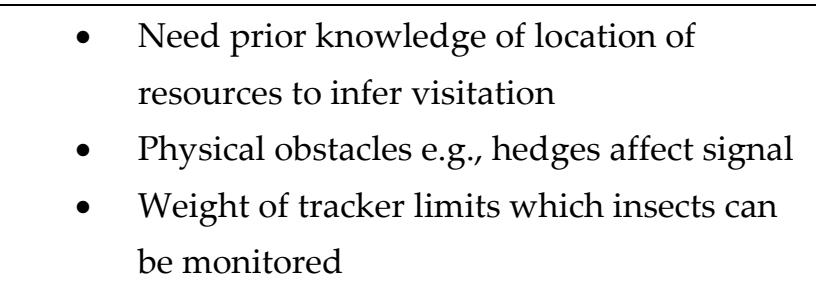 \\
\hline $\begin{array}{l}\text { Pollen } \\
\text { microscopy }\end{array}$ & $\begin{array}{l}\text { Can give information on an } \\
\text { individual's entire foraging } \\
\text { trip } \\
\text { - } \text { Pollinator specimens can be } \\
\text { retained for morphological } \\
\text { identification and voucher } \\
\text { specimens } \\
\text { Can identify pollen from } \\
\text { historic specimens } \\
\text { Automated processes for } \\
\text { identifying images are being } \\
\text { developed } \\
\text { Some measure of abundance is } \\
\text { achievable }\end{array}$ & 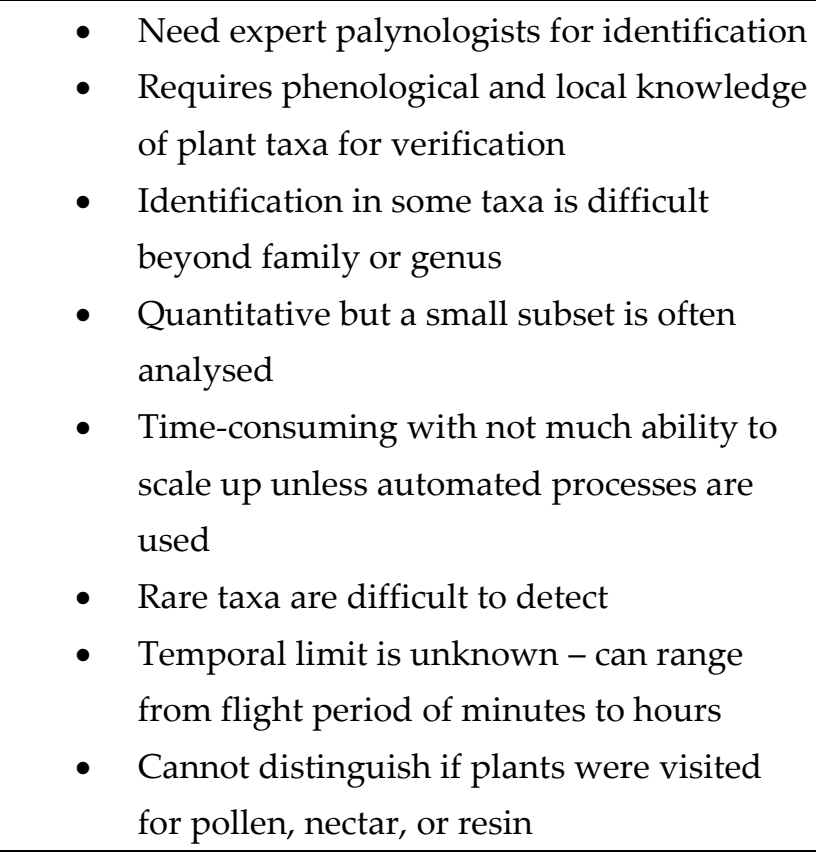 \\
\hline $\begin{array}{l}\text { Pollen } \\
\text { metabarcoding }\end{array}$ & $\begin{array}{l}\text { - Can give information on an } \\
\text { individual's entire foraging } \\
\text { trip } \\
\text { - Can be scaled up easily } \\
\text { - } \quad \text { Pollinator specimens can be } \\
\text { retained for morphological }\end{array}$ & $\begin{array}{l}\text { - Identification in some taxa is difficult } \\
\text { beyond family or genus } \\
\text { - } \text { High start-up costs but can be scaled up } \\
\text { increasing cost effectiveness } \\
\text { - } \quad \text { Rare taxa are difficult to detect } \\
\text { - } \\
\text { Requires phenological and local knowledge } \\
\text { of plant taxa for verification }\end{array}$ \\
\hline
\end{tabular}




\begin{tabular}{|c|c|c|}
\hline & $\begin{array}{l}\text { identification and voucher } \\
\text { specimens } \\
\text { - } \quad \text { Eliminates the need for expert } \\
\text { palynologists } \\
\text { - } \text { Can identify the entire pollen } \\
\text { assemblage of an individual } \\
\text { - Can distinguish taxa which are } \\
\text { difficult to identify } \\
\text { morphologically } \\
\text { Can identify pollen from } \\
\text { historic specimens } \\
\text { Semi-quantitative data can be } \\
\text { obtained }\end{array}$ & $\begin{array}{l}\text { - Temporal limit is unknown - can range } \\
\text { from flight period of minutes to hours } \\
\text { - Cannot distinguish if plants were visited } \\
\text { for pollen, nectar, or resin } \\
\text { Biases during DNA extraction, PCR and } \\
\text { sequencing may reduce how quantitative } \\
\text { the data can be }\end{array}$ \\
\hline Metagenomics & $\begin{array}{l}\text { - Can give information on an } \\
\text { individual's entire foraging } \\
\text { trip } \\
\text { - } \quad \text { Can be scaled up easily } \\
\text { - } \text { Pollinator specimens can be } \\
\text { retained for morphological } \\
\text { identification and voucher } \\
\text { specimens } \\
\text { Eliminates the need for expert } \\
\text { palynologists } \\
\text { Can identify the entire pollen } \\
\text { assemblage of an individual } \\
\text { Can distinguish taxa which are } \\
\text { difficult to identify } \\
\text { morphologically } \\
\text { - Can identify pollen from } \\
\text { historic specimens } \\
\text { Long read lengths } \\
\text { PCR-free processes reduce } \\
\text { possible amplification biases } \\
\text { data }\end{array}$ & $\begin{array}{l}\text { - Identification in some taxa is difficult } \\
\text { beyond family or genus } \\
\text { Expensive, although sequencing costs are } \\
\text { decreasing } \\
\text { - } \text { Reference libraries for identification require } \\
\text { whole genome or genome skims. High } \\
\text { workload to achieve this at scale for many } \\
\text { plant species. } \\
\text { - } \text { Rare taxa are difficult to detect } \\
\text { Requires phenological and local knowledge } \\
\text { of plant taxa for verification } \\
\text { Temporal limit is unknown - can range } \\
\text { from flight period of minutes to hours } \\
\text { Cannot distinguish if plants were visited } \\
\text { for pollen, nectar, or resin }\end{array}$ \\
\hline
\end{tabular}

period of observation is often limited both spatially and temporally, this leads to missed interactions [51]. As a result, sampling effort is a major determining factor of the number of links which are recorded. Some pollinators are thought to visit many plants in one foraging trip [52], therefore by observing plants rather than pollinators, incomplete networks can be formed, and key forage species may be missed. By analyzing pollen loads of bumblebees, Carvell et al. [53] found that the dominant plant in pollen loads was not always the plant the bee had been caught on, demonstrating that observation of floral networks does not reveal all interactions with visitors. 
Insect-focused methods of identifying floral visitation such as DNA metabarcoding and pollen microscopy can reveal interactions which are unseen using observational methods [37,54-58]. These methods are free from the spatial limitations of observations which come as a result of visual bias e.g., height [16] and tag ranges [12], as they provide a record of any resources which have been accessed by the individual which may be up to several kilometers away [59]. On the contrary, during observations the time spent foraging can be recorded, however, it is currently not possible to distinguish the temporal range of pollen found on an insect's body.

Arstingstall et al. [60] found that when comparing plant-pollinator networks characterized by DNA metabarcoding of pollen to those constructed from observations of foraging bees, networks constructed from molecular analysis had increased species richness and reduced specialisation. However, observed interactions can be undetected using DNA metabarcoding and pollen microscopy, owing to their rarity [57] size of plants $[55,60]$, or use for nectar with limited or no pollen production $[37,61]$. These factors reduce the amount of pollen transferred to the insect and therefore identified. The key advantage of using observations over pollen identification is the ability to identify which resource (pollen, nectar, or resin) is being collected when plants are visited [62]; a vital component of pollinator ecology.

The identification of many pollinator species is difficult in the field [63], therefore observational studies are restricted by taxonomic expertise, leading to some studies operating at genus level [64]. Retaining insect specimens used for pollen analysis through microscopy or metabarcoding allows careful identification either through traditional morphology or CO1 barcoding [65], avoiding limitations of identifications in the field and providing a voucher specimen for future reference.

Interactions between plants and pollinators using both plant and insect-focused observations are usually characterized at the species level [9] due to difficulties tracking individuals [11]. The identification of pollen from the body of an insect using DNA metabarcoding or pollen microscopy allows valuable individual foraging preferences to be characterized more easily than in visual surveys [66]. In pollen microscopy, a small sub-sample is fully identified and used to estimate the composition of the total pollen load [67], whereas molecular analysis can sample the entire pollen assemblage on the body of an insect $[40,68]$. Although there is some congruence between the taxa which are difficult to identify using microscopy and those which are indistinguishable using DNA e.g., some taxa within the Rosaceae family [32], both methods may detect additional taxa when compared to the other $[69,70]$. In comparing pollen microscopy and DNA metabarcoding, several authors have found higher taxonomic resolution of plant taxa identified [35,71] and a greater number of species detected [69-72] using DNA metabarcoding. Both methods, however, are subject to the stochasticity of detecting rare taxa $[72,73]$.

Whilst both pollen microscopy and DNA metabarcoding yield valuable individuallevel information on foraging, identification of plant taxa using DNA eliminates the need for expert palynologists for microscopy. Although also time-consuming and initially expensive [74], molecular processes may be easily scaled up [70,75]. The use of semi-quantitative data (discussed in detail within the methodological considerations) also allows plant-pollinator relationships to be measured and can provide a more sensitive representation of diet compared to frequency of occurrence [76]. 


\section{Using DNA metabarcoding to answer questions about pollinator foraging prefer- ences}

The use of DNA metabarcoding to answer ecological questions about pollinator foraging preferences has increased rapidly over recent years alongside key methodological developments (Supporting Data). The questions addressed can be broadly grouped into four topics: (1) How does foraging change throughout time and space? (2) How is foraging affected by resource availability? (3) How are resources partitioned between species and individuals in a plant-pollinator network? (4) What is the relationship between plant use and pollinator health?

\subsection{How does foraging change throughout time and space?}

DNA metabarcoding provides a useful method for monitoring plant use across wide spatiotemporal scales, such as multiple countries or regions [77] and, when compared with historical data, time periods over decades or centuries [32,78,79]. The reproducibility of DNA metabarcoding allows continued sampling of foraging across a species' entire flight period, allowing an understanding of plant selection at specific time points. Danner et al. [80] and Park and Nieh [81] sampled pollen from honeybee hives at regular intervals throughout the year and identified the plant species that were visited using DNA metabarcoding. Both studies found that the amount and diversity of pollen collected was strongly influenced by season, most likely influenced by the phenology of surrounding plants [80,81]. In addition to tracking contemporary foraging habits, DNA metabarcoding has been shown to be a useful tool for analysing pollen from historical specimens $[78,82,83]$. By sequencing pollen obtained from museum specimens, Simanonok et al. [83] successfully identified the plants used by an endangered bumblebee species over 100 years, vastly improving current knowledge of resource use and mechanisms of decline. Similarly, analysing the pollen DNA within UK honey and comparing the plant diversity to samples characterised 65 years prior using microscopy revealed landscape-scale shifts in foraging habits due to changes in agricultural intensification, crop use, and the spread of invasive species [32]. Long-range movements can be tracked by identifying pollen on migrating insects [34,84]. Suchan et al. [84] detected plant species endemic to Africa on butterflies using DNA metabarcoding, significantly improving the understanding of migration patterns which were previously limited when using traditional techniques. As well as increasing the spatial scale of studies, pollen metabarcoding has highlighted the importance of trees and woody species to pollinators, plants with flowers which are often visually restricted and therefore may be missed during observational surveys [31,85]. Whilst most of these spatial assessments of foraging focus on geographic differences, only one study has specifically demonstrated the ability of pollen metabarcoding to elucidate changes in resource use across elevational gradients to better understand how climatic changes in the environment impact foraging [36].

\subsection{How is foraging affected by resource availability?}

A key area of research in pollinator foraging ecology is understanding why specific plants are used and whether this is driven by preferences relating to characteristics of the plant e.g., nectar quality [86], or simply a result of resource availability [87]. By conducting floral surveys and comparing the flowering plants available to the plants identified in honey using DNA metabarcoding, de Vere et al. [31] found that honeybees only used $11 \%$ of genera available. Park \& Nieh [81] also used a metabarcoding method along with herbarium records to illustrate that honeybees used between $2.7-10 \%$ of flowering species available over three seasons.

Insect visitation can be influenced by the abundance of floral resources in a landscape [88], which is affected both temporally by plant phenology [89] and spatially by habitat type [90]. Timberlake [91] utilised a null model method and DNA metabarcoding of pollen 
samples collected from bumblebees within farmland to illustrate that floral choice was not always driven by the abundance of plant species, nor their nectar availability. By identifying plants which are visited more than expected compared to their abundance, management recommendations can be given for maintaining appropriate floral provision aimed at the effective conservation of bumblebees on farmland [91]. Likewise, Jones [92] found no significant correlation between the abundance of plant taxa in the landscape and the abundance of plants found in honey samples each month. However, Nürnberger et al. [93] found that the number of plant genera in pollen loads of honeybees identified by metabarcoding was lower when floral availability was reduced. Recent work by Quinlan et al. [94] suggests that whilst honeybees may sometimes preferentially select plants found in high abundance, this is dependent on the time of year and nutritional demand.

DNA metabarcoding can be used to monitor how spatiotemporal changes in resource availability across landscapes affect the diet of pollinators [77,90,95-97]. By assessing honeybee diet across gradients of land use, multiple authors have found that the richness and diversity of pollen collected is not strongly linked to the composition of surrounding landscapes $[33,70,97,98]$. Instead, seasonality of resources appears to be the greatest driver of diet, irrespective of land use [80,99].

\subsection{How are resources partitioned between species and individuals in plant-pollinator networks?}

The use of DNA-based methods for identifying species interactions allows complex networks to be constructed and analysed [35,100]. Constructing accurate networks is important to help fully understand their structure, as the level of specialisation and generalisation of networks, species, or individuals can affect their robustness against environmental change [101,102].

A number of authors have used molecular approaches to assess resource partitioning within large plant-pollinator networks $[35,66,68]$. Elliott et al. [103] used DNA metabarcoding to construct an interaction network between honeybees, native bees and the floral resources used to identify resource overlap. The number of known floral hosts of many species were increased compared to the previous literature based on observational studies, improving the understanding of how wild and introduced bees coexist in a landscape [103].

The ability to identify an individual's entire pollen assemblage results in the valuable characterisation of interactions at varying hierarchical levels throughout a plantpollinator community [104]. To date, of the studies that have identified resource partitioning within plant-pollinator networks using DNA metabarcoding, all have found that generalised networks or species are made up of specialised individuals $[39,66,68,105]$. This presents a promising area of research to further investigate the levels of specialisation and generalisation exhibited by pollinators.

\subsection{What is the relationship between plant use and pollinator health?}

Floral resources vary in the quality of their nectar and pollen rewards [86], and consequently, the diversity of resources used has been found to impact pollinator fitness [106]. Insights into the nutritional ecology of pollinators can be unearthed using DNA metabarcoding, by quantifying the relationship between plant taxa found and the protein, carbohydrate, lipid, and amino acid content of pollen $[97,107,108]$. For example, Donkersley et al. [107] found that the protein content of bee bread (honeybee pollen stores) was positively correlated with the presence of dandelion Taraxacum spp. pollen and negatively correlated with pollen from cherries and plums Prunus spp., improving our understanding of how floral resources meet the dietary requirements of pollinators. 
As well as affecting the nutritional quality of provisions, the plant species visited by pollinators may also influence the bacteria present in the nest [109]. DNA metabarcoding allows plant-microbe relationships to be explored, increasing the understanding of plant-pollinator interactions throughout an insect's lifecycle. The relationship between the diversity of pollen species collected and the diversity of the microbiome appears complex. However, both positive and negative associations have been found between particular pollen types and bacteria [110-112]. For example, Voulgari-Kokota et al. [112] found that the presence of Acinetobacteria in pollen provisions of a solitary bee was positively associated with the presence of some taxa such as European goldenrod Solidago virgaurea, oxeye daisy Leucanthemum vulgare and yarrow Achillea millefolium, but negatively associated with spear thistle Cirsium vulgare, red poppy Papaver rhoeas and sycamore Acer pseudoplatanus.

The identification of pollen in nests has also been used to investigate the relationship between mass-flowering crops and the prevalence of parasites, finding that increased abundance of resources may help to reduce transmission by diluting parasite transmission through reducing visitation frequency per flower [113].

\section{Key methodological considerations for using DNA approaches and their challenges}

\subsection{Study design and sampling}

Careful considerations are required for every stage of the molecular approach, from the initial stages of study design to the downstream bioinformatic analysis (Table 2). Firstly, the nature of the study system must be considered in order to understand the information which will be produced. For example, sampling pollen from a single bee which is actively foraging will yield different results to pollen collected through pollen traps or honey, as the latter methods represent the foraging efforts of multiple bees over numerous trips [31]. In addition, morphological features such as body size and pilosity (hairiness) of insects can influence the number and diversity of pollen retained [114]. Pollen may be transferred from plants visited solely for nectar [62], and some plants do not produce nectar at all [115]. In addition, nectar can itself be contaminated with pollen as a result of plant visitors [116]. Therefore, molecular analysis of pollen generates information on which plants have been visited for both pollen and nectar collection. Another important consideration is that the presence of pollen on insects does not assume pollination has occurred [117], therefore the identification of pollen represents floral visitation only. It is also important to consider that when identifying plant material within nest provisions, contamination may occur from multiple sources of plant DNA such as pollen provisions, leaf or soil material used to build nests [71].

Capturing methods such as on transect walks or during observations will also influence the number and diversity of insects caught and therefore the resulting sampling universe. The flight times of insects and phenology of plants must also be considered due to their influence on foraging. For example, sampling one species across its entire flight period will give a more complete picture of resources used compared to studies undertaken within a shorter time period, which have limited information on the total resources used.

The nature of pollen sampling from insect bodies results in a risk of cross-contamination occurring in the field, therefore, samples should be collected using a combination of nets and sterile tubes, with nets changed regularly and sterilised between surveys [39]. 
Table 2. Key considerations required for each step of the pollen metabarcoding workflow

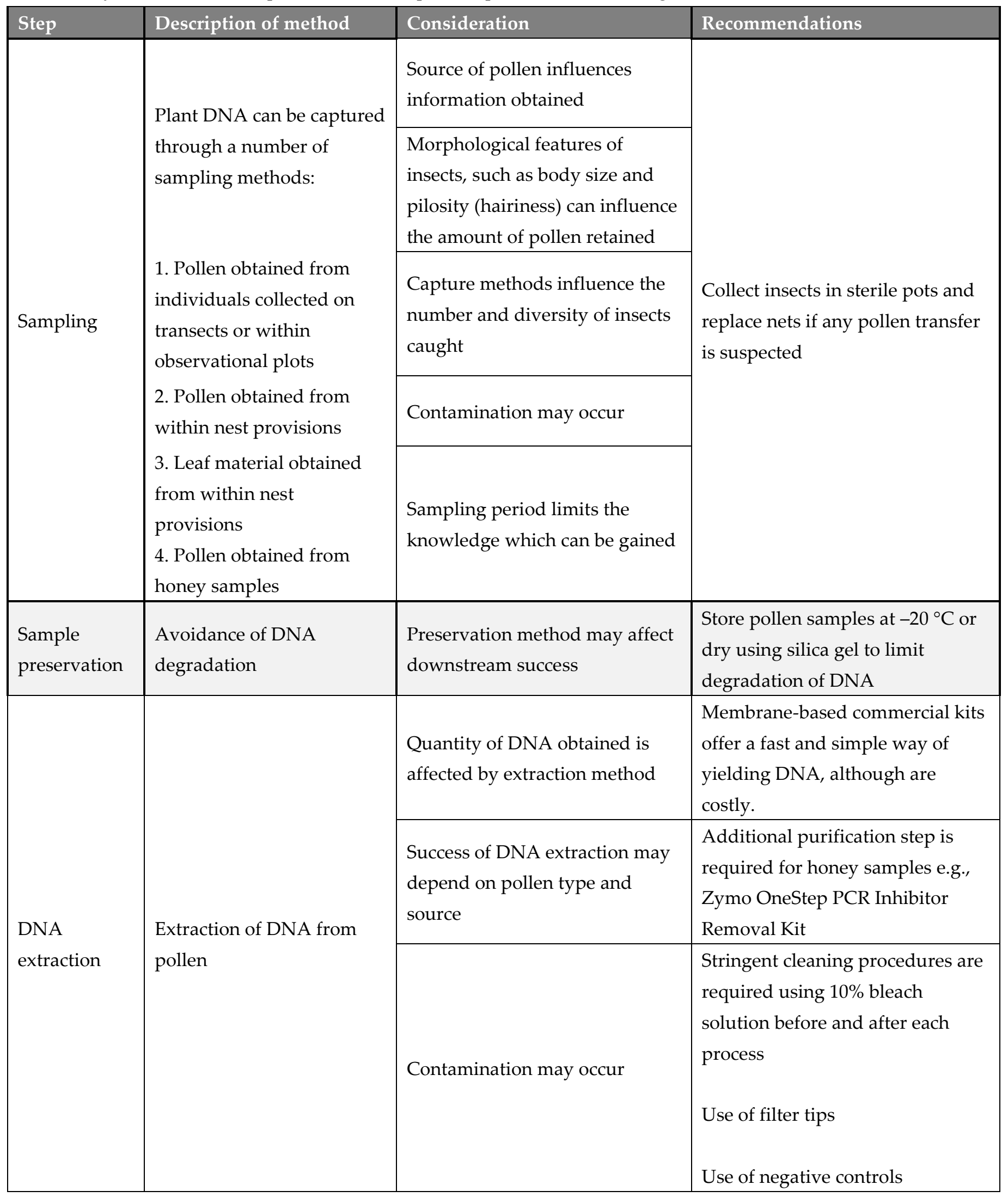




\begin{tabular}{|c|c|c|c|}
\hline \multirow{5}{*}{ Amplification } & \multirow{5}{*}{$\begin{array}{l}\text { PCR amplification of } \\
\text { extracted DNA using } \\
\text { primers which target } \\
\text { specific region of interest }\end{array}$} & $\begin{array}{l}\text { Choice of marker will influence } \\
\text { which taxa are recovered and } \\
\text { their taxonomic resolution }\end{array}$ & $\begin{array}{l}\text { We recommend a multi-locus } \\
\text { approach using rbcL and ITS2 } \\
\text { Primer recommendations in Table } \\
\text { S1, Supporting Information }\end{array}$ \\
\hline & & Contamination may occur & $\begin{array}{l}\text { Stringent cleaning procedures are } \\
\text { required using } 10 \% \text { bleach } \\
\text { solution before and after each } \\
\text { process }\end{array}$ \\
\hline & & & Use of filter tips \\
\hline & & & $\begin{array}{l}\text { Use of positive and negative } \\
\text { controls }\end{array}$ \\
\hline & & $\begin{array}{l}\text { Biases may be introduced } \\
\text { through primer specificity }\end{array}$ & $\begin{array}{l}\text { Complete three rounds of PCR } \\
\text { per sample and pool }\end{array}$ \\
\hline $\begin{array}{l}\text { Multiplexing } \\
\text { and library } \\
\text { preparation }\end{array}$ & $\begin{array}{l}\text { Addition of nucleotide } \\
\text { sequences to primers to } \\
\text { allow for pooling of } \\
\text { samples and compatibility } \\
\text { with sequencing platforms }\end{array}$ & $\begin{array}{l}\text { Each method has a trade-off } \\
\text { between multiple factors } \\
\text { including overall cost, risk of } \\
\text { contamination and PCR } \\
\text { efficiency } \\
\text { Tag-jumping can occur causing } \\
\text { misidentification }\end{array}$ & $\begin{array}{l}\text { Index strategy used should be } \\
\text { based on research question and } \\
\text { experimental set-up } \\
\text { A two-step PCR approach allows } \\
\text { cost effective indexing }\end{array}$ \\
\hline Sequencing & $\begin{array}{l}\text { Identification of nucleotide } \\
\text { sequences }\end{array}$ & $\begin{array}{l}\text { Sequencing strategy is } \\
\text { dependent on choice of marker }\end{array}$ & $\begin{array}{l}\text { Illumina MiSeq }(2 \times 300 \mathrm{bp}) \text { allows } \\
\text { sequencing of } r b c L \text { and ITS2 }\end{array}$ \\
\hline $\begin{array}{l}\text { Reference } \\
\text { library }\end{array}$ & $\begin{array}{l}\text { Comparison of DNA } \\
\text { sequences to a reference } \\
\text { library for identification }\end{array}$ & $\begin{array}{l}\text { Identifications made through } \\
\text { DNA metabarcoding will only } \\
\text { be as good as the reference } \\
\text { library }\end{array}$ & $\begin{array}{l}\text { Create a reference library which is } \\
\text { appropriate to the question being } \\
\text { asked and ensure that it is } \\
\text { complete and well curated }\end{array}$ \\
\hline Bioinformatic & $\begin{array}{l}\text { Automated processes used } \\
\text { to curate sequences for }\end{array}$ & $\begin{array}{l}\text { Species may be incorrectly } \\
\text { assigned during automated } \\
\text { processes }\end{array}$ & $\begin{array}{l}\text { Requires manual verification } \\
\text { steps by someone with } \\
\text { knowledge of relevant plant taxa }\end{array}$ \\
\hline analysis & $\begin{array}{l}\text { analysis including quality } \\
\text { control }\end{array}$ & $\begin{array}{l}\text { Metabarcoding data is } \\
\text { considered to be semi- } \\
\text { quantitative }\end{array}$ & $\begin{array}{l}\text { Treat proportion of sequences as } \\
\text { relative read abundance for } \\
\text { analysis }\end{array}$ \\
\hline
\end{tabular}

Airborne pollen may also contaminate samples [56], leading some authors to use thresholds to exclude rare taxa (reviewed in [118]) or removing all wind-pollinated species from analysis [119]. However, it should be noted that rare taxa may include real interactions, and some pollinators are known to visit wind-pollinated plants [120,121]. Further work to quantify the prevalence of residual pollen left on plants by insect visitors would be useful to infer thresholds for removal [60]. The method of preserving samples may 
also affect the success of the study [122]. Whilst successful sequencing of pollen from historical specimens is possible [78], samples should be preserved quickly to avoid degradation of DNA. Most pollen metabarcoding studies have preserved samples by freezing at $20{ }^{\circ} \mathrm{C}$, however, recent work by Quaresma et al., [123] suggests that the use of silica gel for preserving pollen should not be overlooked, particularly when samples are collected by citizen scientists.

\subsection{DNA extraction}

Numerous DNA isolation methods exist which can influence the quality of the DNA template [124,125]. Membrane-based isolation techniques are most commonly used for pollen metabarcoding studies, providing a fast and simple way of yielding DNA, although are costly [124]. Prior to amplification, additional purification steps may be required to remove PCR inhibitors, this is common when using honey as a source of pollen [32].

\subsection{Amplification}

The choice of barcode marker is regarded as one of the most important considerations of DNA barcoding studies and its applications, ultimately affecting the number of taxa recovered and the level of species discrimination obtained [126]. DNA barcode markers require high universality so that a large proportion of species in a sample are amplified, but also low intra-specific and high inter-specific variation for effective species discrimination [127]. Short markers allow amplification of degraded DNA, however, these come with a caveat of reduced taxonomic resolution [128].

There is no single marker which meets the ideal requirements for a plant barcode, however, the standard markers are rbcL and matK, with trnH-psbA and ITS2 being used as additional markers for increased species discrimination [127]. For pollen metabarcoding, five regions are commonly used: rbcL, ITS2, matK, trnL and trnH-psbA (Supporting Information). A multi-locus approach is recommended to ensure the greatest number of taxa are identified $[21,32,128]$. The length of matK (800 bp), restricts its use in metabarcoding due to limitations in read length on standard sequencing platforms [126]. Therefore, it is recommended that rbcL and ITS2 are used for pollen metabarcoding, due to their ability to identify taxa at varying taxonomic levels along with additional taxa unique to one marker which provides accurate identification of plant species within mixed pollen samples [32,40,60].

Contamination may also occur in the laboratory; therefore, stringent cleaning procedures are required to minimize these risks. The use of controls (negative in extraction, positive and negative in PCR) helps identify sources of contamination and should be sequenced with samples [32,129]. If sequences occur in negative controls, the number of reads of each taxon should be removed from all samples [74].

\subsection{Multiplexing and library preparation}

The ability to scale up metabarcoding studies relies on the use of sample-specific labels in the form of unique sequences of nucleotides which are attached to amplicons. These unique identifiers allow hundreds or thousands of samples to be pooled for sequencing (multiplexing), significantly increasing the capacity of one sequencing run. Methods for indexing of samples occur either during the initial PCR through nucleotide additions to amplicons or through a secondary PCR along with adapters to allow successful sequencing (library indices) (reviewed in [130]). Each of the methods comes with tradeoffs between many factors, mainly the risk of cross-contamination, efficiency of PCR and overall cost [130]. The two-step PCR approach is most widely used in pollen 
metabarcoding studies (Supporting Information), allowing a cost-effective approach to sample labelling whilst allowing effective detection of cross-contamination, but comes with the caveat of increased risk of biases due to an additional amplification stage [130].

\subsection{Sequencing}

Following amplification of DNA, the sequencing strategy used is dependent on a variety of factors including the choice of marker, with most studies thus far utilising the Illumina MiSeq platform. Although concerns are raised over the maximum read length of Illumina platforms ( 2 × $300 \mathrm{bp}$ ) [26,84], multiple studies have demonstrated successful sequencing of longer markers such as rbcL $(\sim 500 \mathrm{bp})$ along with additional adapters and primers [40,61]. Newer sequencing technologies such as the MinION (Oxford Nanopore Technologies) and SMRT platform (PACBIO, Pacific Biosciences) produce longer read lengths, however, generate less reads than Illumina [26]. In addition, the requirement for high quality and quantity of input DNA may be a limiting factor for some applications of these technologies [47].

\subsection{Reference library}

The accuracy of DNA barcoding is reliant on a comprehensive reference library [126,131]. The creation of large-scale, complete DNA barcode reference libraries for a national flora has been achieved in the UK [126,132] and Canada [133] using a multi-locus approach, allowing reliable species identification in subsequent pollen metabarcoding studies [31,32]. The curation of reference libraries from chloroplast genomes and nuclear ribosomal DNA sequences can also provide coverage of standard barcodes, however, these methods are more costly [134]. If a complete regional reference database is not available [135] then authors are encouraged to compile custom, relevant reference libraries using the sequences available in GenBank. Curation of these libraries is required however to identify and remove incorrect sequences [60,98,103,136]. It is critically important to understand the coverage of the reference library being used compared to the plant taxa that could be detected [126].

\subsection{Bioinformatic analysis}

The quantity of data produced from DNA metabarcoding studies requires automated processes for curation of sequences, including steps for quality control. The main purpose of this process is to remove any additional nucleotide sequences (index tags, adapter tags and primers) and to separate each sample for subsequent analysis (demultiplexing). The reduction of the need for expert taxonomists to identify pollen grains is often cited as one of the major advantages of molecular methods over pollen microscopy [78]. However, few authors highlight the importance of having good knowledge of the taxonomic group in question (i.e., plants in pollen metabarcoding), including their distribution and phenology for accurate species identification [31,32,70,137]. Misidentifications may occur during the bioinformatic process due to low interspecific variance [126] or incorrectly identified sequences in GenBank [138]. In order to mitigate misidentifications, deployment of a manual verification step in the assignment process, underpinned by botanical expertise, will reduce incorrect species assignments.

\subsection{Towards standardisation of methods}

Although each step of the pollen metabarcoding process has a range of different approaches, only certain elements of the entire pollen metabarcoding workflow have been reviewed [118,125,130], leaving a large proportion of the study design to the authors' discretion. Without a standardisation of approaches, comparison of results across multiple studies must be interpreted with caution. Until each stage has been critically 
reviewed and a robust, standardised approach is established, we encourage researchers to carefully assess the considerations outlined in Fig. 1 for guidance prior to conducting a pollen metabarcoding study. Further, we call upon authors to be transparent in reporting every aspect of their molecular methods to ensure studies are reproducible, utilising supporting information where word limits are restricting.

\subsection{How quantitative is DNA metabarcoding?}

Finally, there is continued debate over whether DNA metabarcoding may characterise pollen samples in a quantitative manner, with mixed results across studies $[57,69,71,139,140]$. Quantification has been found to be affected by a combination of marker and primer used, pollen type, mixture characteristics and PCR conditions [73,141143]. It is likely that relationships between the proportion of DNA reads and pollen counts are more likely for the most abundant taxa within a sample [70,144]. Similar to microscopy, rare taxa are difficult to detect using pollen metabarcoding [72]. Whilst this is a limitation, studies examining insect floral resource use often place greater focus on those plants detected at higher abundance. For this reason, along with the potential biases which can occur, DNA metabarcoding should be considered as semi-quantitative and relative read abundance used for downstream analysis [76]. We do not recommend the use of presence/absence approaches due to rare taxa being overstated and abundant taxa devalued [76].

\section{Opportunities and future directions}

The use of DNA metabarcoding as a tool to investigate pollinator foraging has allowed increased insight into the interactions between plants and pollinators, however, it is still a developing field. Most studies focus on the identification of pollen; however, other plant material may be used to identify relationships between insects and plants. For example, recently, the characterization of resin within the nests of solitary bees through DNA metabarcoding has been suggested as a promising approach to identify which plants are important for nest building [145]. DNA metabarcoding is also not free from limitations. Overall, the biggest limitation is the cost and reproducibility of the molecular techniques [146], which determine which methods are used. Whilst the interpretation of data remains semi-quantitative, future work may lead to the ability to accurately measure pollen abundance, significantly improving the application of this technique [142,143]. Quantification may be improved by using PCR-free approaches which also provide a greater representation of the genome [44]. Recent work by Bell et al. [44] has demonstrated that wholegenome shotgun sequencing of pollen DNA is a reliable method for identification of pollen species mixtures. However, coverage of eukaryotic organisms in reference libraries remains low, and assembly of whole genomes is currently more expensive than metabarcoding per sample [44]. It is likely that DNA metabarcoding will remain the standard technique until genome-level coverage improves. Until then, genome-skimming techniques may hold promise to identify beyond the species level e.g., to population or individual, if the nuclear genome is retained [147].

\section{Final Remarks}

This review describes the range of approaches available to investigate floral visitation by pollinators using DNA metabarcoding. We demonstrate how the ability to yield valuable individual- to community- level information on foraging over large spatiotemporal scales allows a breadth of ecological questions to be explored, for the benefit of both the conservation of pollinators and the maintenance of the ecosystem services they provide. DNA 
metabarcoding has become a standard tool for the characterization of complex plant-pollinator interactions, allowing improved understanding of threatened global biodiversity.

Supplementary Materials: The following supporting information can be downloaded at: www.mdpi.com/xxx/s1, Table S1: Recommended primer sequences used to amplify the $r b c L$ and ITS2 barcode regions. Table S2: Details of studies which use plant DNA metabarcoding to identify floral visitation by pollinators or developed methods to support.

Author Contributions: Conceptualization, AL, NdV and SC; Methodology, AL and NdV; Validation, AL, LJ, LW, SC and NdV; Investigation, AL; Data Curation, AL; Writing - Original Draft Preparation, AL and NdV; Writing - Review \& Editing, AL, LJ, LW, SC and NdV; Supervision, NdV and SC; Funding Acquisition, NdV.

Funding: AL, LJ and NdV have received funding through the Welsh Government Rural Communities - Rural Development Programme 2014-2020, which is funded by the European Agricultural Fund for Rural Development and the Welsh Government. AL and LW were supported by a Knowledge Economy Skills Scholarship (KESS2), part funded by the Welsh Government's European Social Fund (ESF).

Institutional Review Board Statement: Not applicable.

Data Availability Statement: All relevant data are provided in Supplementary Materials.

Conflicts of Interest: The authors declare no conflict of interest.

\section{References}

1. Klein, A.-M.; Vaissiere, B.E.; Cane, J.H.; Steffan-Dewenter, I.; Cunningham, S.A.; Kremen, C.; Tscharntke, T. Importance of pollinators in changing landscapes for world crops. Proc. R. Soc. B Biol. Sci. 2007, 274, 303-313, doi:10.1098/rspb.2006.3721.

2. Potts, S.G.; Imperatriz-Fonseca, V.; Ngo, H.T.; Aizen, M.A.; Biesmeijer, J.C.; Breeze, T.D.; Dicks, L. V.; Garibaldi, L.A.; Hill, R.; Settele, J.; et al. Safeguarding pollinators and their values to human well-being. Nature 2016, 540, 220-229, doi:10.1038/nature20588.

3. Ollerton, J. Pollinator Diversity: Distribution, Ecological Function, and Conservation. Annu. Rev. Ecol. Evol. Syst. 2017, 48, annurev-ecolsys-110316-022919, doi:10.1146/annurev-ecolsys-110316-022919.

4. Powney, G.D.; Carvell, C.; Edwards, M.; Morris, R.K.A.; Roy, H.E.; Woodcock, B.A.; Isaac, N.J.B. Widespread losses of pollinating insects in Britain. Nat. Commun. 2019, 10, 1-6, doi:10.1038/s41467-019-08974-9.

5. Wepprich, T.; Adrion, J.R.; Ries, L.; Wiedmann, J.; Haddad, N.M. Butterfly abundance declines over 20 years of systematic monitoring in Ohio, USA. PLoS One 2019, 14, 1-21, doi:10.1371/journal.pone.0216270.

6. Dicks, L. V; Breeze, T.D.; Ngo, H.T.; Senapathi, D.; An, J.; Aizen, M.A.; Basu, P.; Buchori, D.; Galetto, L.; Garibaldi, L.A.; et al. A global-scale expert assessment of drivers and risks associated with pollinator decline. Nat. Ecol. Evol. 2021, doi:10.1038/s41559021-01534-9.

7. Goulson, D.; Lye, G.C.; Darvill, B. Diet breadth, coexistence and rarity in bumblebees. Biodivers. Conserv. 2008, 17, 3269-3288, doi:10.1007/s10531-008-9428-y.

8. Hanley, M.E.; Awbi, A.J.; Franco, M. Going native? Flower use by bumblebees in English urban gardens. Ann. Bot. 2014, 113, 799-806, doi:10.1093/aob/mcu006.

9. Klečka, J.; Hadrava, J.; Biella, P.; Akter, A. Flower visitation by hoverflies (Diptera: Syrphidae) in a temperate plant-pollinator network. PeerJ 2018, 2018, doi:10.7717/peerj.6025.

10. Sutherland, J.P.; Sullivan, M.S.; Poppy, G.M. The influence of floral character on the foraging behaviour of the hoverfly, Episyrphus balteatus. Entomol. Exp. Appl. 1999, 93, 157-164, doi:10.1023/A:1003844307934.

11. Heinrich, B. The foraging specializations of individual bumblebees. Ecol. Monogr. 1976, 46, 105-128, doi:10.1016/S00033472(89)80111-3.

12. Osborne, J.L.; Clark, S.J.; Morris, R.J.; Williams, I.H.; Riley, J.R.; Smith, A.D.; Reynolds, D.R.; Edwards, A.S. A landscape-scale study of bumble bee foraging range and constancy, using harmonic radar. J. Appl. Ecol. 1999, 36, 519-533, doi:10.1046/j.13652664.1999.00428.x.

13. Seeley, T. The wisdom of the hive.; Harvard University Press: London, 1995;

14. Balfour, N.J.; Fensome, K.A.; Samuelson, E.E.W.; Ratnieks, F.L.W. Following the dance: Ground survey of flowers and flowervisiting insects in a summer foraging hotspot identified via honey bee waggle dance decoding. Agric. Ecosyst. Environ. 2015, 213, 265-271, doi:10.1016/j.agee.2015.08.007.

15. Eckhardt, M.; Haider, M.; Dorn, S.; Müller, A. Pollen mixing in pollen generalist solitary bees: A possible strategy to complement or mitigate unfavourable pollen properties? J. Anim. Ecol. 2014, 83, 588-597, doi:10.1111/1365-2656.12168.

16. Wood, T.J.; Holland, J.M.; Goulson, D. Diet characterisation of solitary bees on farmland: dietary specialisation predicts rarity. Biodivers. Conserv. 2016, 25, 2655-2671, doi:10.1007/s10531-016-1191-x. 
17. Ebenezer, I.O.; Olugbenga, M.T. Pollen characterisation of honey samples from North Central Nigeria. J. Biol. Sci. 2010, 10, 4347, doi:10.3923/jbs.2010.43.47.

18. Ponnuchamy, R.; Bonhomme, V.; Prasad, S.; Das, L.; Patel, P.; Gaucherel, C.; Pragasam, A.; Anupama, K. Honey pollen: Using melissopalynology to understand foraging preferences of bees in tropical south India. PLoS One 2014, 9, doi:10.1371/journal.pone.0101618.

19. Lawson, S.P.; Ciaccio, K.N.; Rehan, S.M. Maternal manipulation of pollen provisions affects worker production in a small carpenter bee. Behav. Ecol. Sociobiol. 2016, 70, 1891-1900, doi:10.1007/s00265-016-2194-z.

20. Williams, N.M.; Kremen, C. Resource distributions among habitats determine solitary bee offspring production in a mosaic landscape. Ecol. Appl. 2007, 17, 910-921, doi:10.1890/06-0269.

21. Bell, K.L.; de Vere, N.; Keller, A.; Richardson, R.T.; Gous, A.; Burgess, K.S.; Brosi, B.J. Pollen DNA barcoding: current applications and future prospects. Genome 2016, 59, 629-640, doi:10.1139/gen-2015-0200.

22. Holt, K.A.; Bennett, K.D. Principles and methods for automated palynology. New Phytol. 2014, 203, 735-742, doi:10.1111/nph.12848.

23. Polling, M.; Li, C.; Cao, L.; Verbeek, F.; de Weger, L.A.; Belmonte, J.; De Linares, C.; Willemse, J.; de Boer, H.; Gravendeel, B. Neural networks for increased accuracy of allergenic pollen monitoring. Sci. Rep. 2021, 11, 1-10, doi:10.1038/s41598-021-90433$\mathrm{x}$.

24. Sevillano, V.; Aznarte, J.L. Improving classification of pollen grain images of the POLEN23E dataset through three different applications of deep learning convolutional neural networks. PLoS One 2018, 13, 1-18, doi:10.1371/journal.pone.0201807.

25. Cristescu, M.E. From barcoding single individuals to metabarcoding biological communities: Towards an integrative approach to the study of global biodiversity. Trends Ecol. Evol. 2014, 29, 566-571, doi:10.1016/j.tree.2014.08.001.

26. Evans, D.M.; Kitson, J.J. Molecular ecology as a tool for understanding pollination and other plant-insect interactions. Curr. Opin. Insect Sci. 2020, 38, 26-33, doi:10.1016/j.cois.2020.01.005.

27. Leidenfrost, R.M.; Bänsch, S.; Prudnikow, L.; Brenig, B.; Westphal, C.; Wünschiers, R. Analyzing the Dietary Diary of Bumble Bee. Front. Plant Sci. 2020, 11, 1-9, doi:10.3389/fpls.2020.00287.

28. Eeraerts, M.; Piot, N.; Pisman, M.; Claus, G.; Meeus, I.; Smagghe, G. Landscapes with high amounts of mass-flowering fruit crops reduce the reproduction of two solitary bees. Basic Appl. Ecol. 2021, 56, 122-131, doi:10.1016/j.baae.2021.07.005.

29. Gresty, C.E.A.; Clare, E.; Devey, D.S.; Cowan, R.S.; Csiba, L.; Malakasi, P.; Lewis, O.T.; Willis, K.J. Flower preferences and pollen transport networks for cavity-nesting solitary bees: Implications for the design of agri-environment schemes. Ecol. Evol. 2018, 1-14, doi:10.1002/ece3.4234.

30. Vaudo, A.D.; Biddinger, D.J.; Sickel, W.; Keller, A.; López-Uribe, M.M. Introduced bees (Osmia cornifrons) collect pollen from both coevolved and novel host-plant species within their family-level phylogenetic preferences (Royal Society Open Science (2020) 7 (200225) DOI: 10.1098/rsos.200225). R. Soc. Open Sci. 2020, 7, doi:10.1098/rsos.201375.

31. de Vere, N.; Jones, L.E.; Gilmore, T.; Moscrop, J.; Lowe, A.; Smith, D.; Hegarty, M.J.; Creer, S.; Ford, C.R. Using DNA metabarcoding to investigate honey bee foraging reveals limited flower use despite high floral availability. Sci. Rep. 2017, 7, 1-10, doi:10.1038/srep42838.

32. Jones, L.; Brennan, G.L.; Lowe, A.; Creer, S.; Ford, C.R.; de Vere, N. Shifts in honeybee foraging reveal historical changes in floral resources. Commun. Biol. 2021, 4, 37, doi:10.1038/s42003-020-01562-4.

33. Lucek, K.; Galli, A.; Gurten, S.; Hohmann, N.; Maccagni, A.; Patsiou, T.; Willi, Y. Metabarcoding of honey to assess differences in plant-pollinator interactions between urban and non-urban sites. Apidologie 2019, 50, 317-329, doi:10.1007/s13592-01900646-3.

34. Chang, H.; Guo, J.; Fu, X.; Liu, Y.; Wyckhuys, K.A.G.; Hou, Y.; Wu, K. Molecular-assisted pollen grain analysis reveals spatiotemporal origin of long-distance migrants of a noctuid moth. Int. J. Mol. Sci. 2018, 19, doi:10.3390/ijms19020567.

35. Macgregor, C.J.; Kitson, J.J.N.; Fox, R.; Hahn, C.; Lunt, D.H.; Pocock, M.J.O.; Evans, D.M. Construction, validation, and application of nocturnal pollen transport networks in an agro-ecosystem: a comparison using light microscopy and DNA metabarcoding. Ecol. Entomol. 2019, 44, 17-29, doi:10.1111/een.12674.

36. Mayr, A. V.; Keller, A.; Peters, M.K.; Grimmer, G.; Krischke, B.; Geyer, M.; Schmitt, T.; Steffan-Dewenter, I. Cryptic species and hidden ecological interactions of halictine bees along an elevational gradient. Ecol. Evol. 2021, 11, 7700-7712, doi:10.1002/ece3.7605.

37. Wilson, E.E.; Sidhu, C.S.; Levan, K.E.; Holway, D. a. Pollen foraging behaviour of solitary Hawaiian bees revealed through molecular pollen analysis. Mol. Ecol. 2010, 19, 4823-4829, doi:10.1111/j.1365-294X.2010.04849.x.

38. Fahimee, J.; Badrulisham, A.S.; Zulidzham, M.S.; Reward, N.F.; Muzammil, N.; Jajuli, R.; Md-Zain, B.M.; Yaakop, S. Metabarcoding in diet assessment of Heterotrigona itama based on trnL marker towards domestication program. Insects 2021, 12, 116, doi:10.3390/insects12030205.

39. Lucas, A.; Bodger, O.; Brosi, B.J.; Ford, C.R.; Forman, D.W.; Greig, C.; Hegarty, M.; Neyland, P.J.; de Vere, N. Generalisation and specialisation in hoverfly (Syrphidae) grassland pollen transport networks revealed by DNA metabarcoding. J. Anim. Ecol. 2018, 87, 1008-1021, doi:10.1111/1365-2656.12828.

40. Lowe, A.; Jones, L.; Brennan, G.L.; Creer, S.; de Vere, N. Seasonal progression and differences in major floral resource use by bees and hoverflies in a diverse horticultural and agricultural landscape revealed by DNA metabarcoding. J. Appl. Ecol. Press.

41. MacIvor, J.S. DNA barcoding to identify leaf preference of leafcutting bees. R. Soc. Open Sci. 2016, 3, 150623, doi:10.1098/rsos.150623. 
42. Müller, A.; Prosi, R.; Praz, C.; Richter, H. Nesting in bark - the peculiar life history of the rare boreoalpine osmiine bee Osmia (Melanosmia) nigriventris (Hymenoptera, Megachilidae). Alp. Entomol. 2019, 3, 105-119, doi:10.3897/alpento.3.34409.

43. Müller, A.; Richter, H. Dual function of Potentilla (Rosaceae) in the life history of the rare boreoalpine osmiine bee Hoplitis (Formicapis) robusta (Hymenoptera, Megachilidae). Alp. Entomol. 2018, 2, 139-147, doi:10.3897/alpento.2.30158.

44. Bell, K.L.; Petit, R.A.; Cutler, A.; Dobbs, E.K.; Macpherson, J.M.; Read, T.D.; Burgess, K.S.; Brosi, B.J. Comparing whole-genome shotgun sequencing and DNA metabarcoding approaches for species identification and quantification of pollen species mixtures. Ecol. Evol. 2021, 1-17, doi:10.1002/ece3.8281.

45. Creer, S.; Deiner, K.; Frey, S.; Porazinska, D.; Taberlet, P.; Thomas, W.K.; Potter, C.; Bik, H.M. The ecologist's field guide to sequence-based identification of biodiversity. Methods Ecol. Evol. 2016, 7, 1008-1018.

46. Lang, D.; Tang, M.; Hu, J.; Zhou, X. Genome-skimming provides accurate quantification for pollen mixtures. Mol. Ecol. Resour. 2019, 19, 1433-1446, doi:10.1111/1755-0998.13061.

47. Peel, N.; Dicks, L. V.; Clark, M.D.; Heavens, D.; Percival-Alwyn, L.; Cooper, C.; Davies, R.G.; Leggett, R.M.; Yu, D.W. Semiquantitative characterisation of mixed pollen samples using MinION sequencing and Reverse Metagenomics (RevMet). Methods Ecol. Evol. 2019, 10, 1690-1701, doi:10.1111/2041-210X.13265.

48. Thomsen, P.F.; Sigsgaard, E.E. Environmental DNA metabarcoding of wild flowers reveals diverse communities of terrestrial arthropods. 2019, 1665-1679, doi:10.1002/ece3.4809.

49. Aizenberg-Gershtein, Y.; Izhaki, I.; Halpern, M. Do Honeybees Shape the Bacterial Community Composition in Floral Nectar? PLoS One 2013, 8, doi:10.1371/journal.pone.0067556.

50. Ushio, M.; Yamasaki, E.; Takasu, H.; Nagano, A.J.; Fujinaga, S.; Honjo, M.N.; Ikemoto, M.; Sakai, S.; Kudoh, H. Microbial communities on flower surfaces act as signatures of pollinator visitation. Sci. Rep. 2015, 5, 1-7, doi:10.1038/srep08695.

51. Olesen, J.M.; Bascompte, J.; Dupont, Y.L.; Elberling, H.; Rasmussen, C.; Jordano, P. Missing and forbidden links in mutualistic networks. Proc. R. Soc. B Biol. Sci. 2011, 278, 725-732, doi:10.1098/rspb.2010.1371.

52. Beil, M.; Horn, H.; Schwabe, A. Analysis of pollen loads in a wild bee community (Hymenoptera: Apidae) - a method for elucidating habitat use and foraging distances*. Apidologie 2008, 39, 456-467, doi:10.1051/apido:2008021.

53. Carvell, C.; Westrich, P.; Meek, W.R.; Pywell, R.F.; Nowakowski, M. Assessing the value of annual and perennial forage mixtures for bumblebees by direct observation and pollen analysis. Apidologie 2006, 37, 326-340, doi:10.1051/apido:2006002.

54. de Manincor, N.; Hautekèete, N.; Mazoyer, C.; Moreau, P.; Piquot, Y.; Schatz, B.; Schmitt, E.; Zélazny, M.; Massol, F. How biased is our perception of plant-pollinator networks? A comparison of visit- and pollen-based representations of the same networks. Acta Oecologica 2020, 105, 103551, doi:10.1016/j.actao.2020.103551.

55. Galliot, J.N.; Brunel, D.; Bérard, A.; Chauveau, A.; Blanchetête, A.; Lanore, L.; Farruggia, A. Investigating a flower-insect forager network in a mountain grassland community using pollen DNA barcoding. J. Insect Conserv. 2017, 21, 1-11, doi:10.1007/s10841-017-0022-z.

56. Pornon, A.; Andalo, C.; Burrus, M.; Escaravage, N. DNA metabarcoding data unveils invisible pollination networks. Sci. Rep. 2017, 7, 1-11, doi:10.1038/s41598-017-16785-5.

57. Pornon, A.; Escaravage, N.; Burrus, M.; Holota, H.; Khimoun, A.; Mariette, J.; Pellizzari, C.; Iribar, A.; Etienne, R.; Taberlet, P.; et al. Using metabarcoding to reveal and quantify plant-pollinator interactions. Sci. Rep. 2016, 6, 1-12, doi:10.1038/srep27282.

58. Zhao, Y.H.; Lázaro, A.; Ren, Z.X.; Zhou, W.; Li, H.D.; Tao, Z. Bin; Xu, K.; Wu, Z.K.; Wolfe, L.M.; Li, D.Z.; et al. The topological differences between visitation and pollen transport networks: a comparison in species rich communities of the HimalayaHengduan Mountains. Oikos 2019, 128, 551-562, doi:10.1111/oik.05262.

59. Beekman, M.; Ratnieks, F.L.W. Long-range foraging by the honey-bee, Apis mellifera L. Funct. Ecol. 2000, 14, 490-496, doi:10.1046/j.1365-2435.2000.00443.x.

60. Arstingstall, K.A.; DeBano, S.J.; Li, X.; Wooster, D.E.; Rowland, M.M.; Burrows, S.; Frost, K. Capabilities and limitations of using DNA metabarcoding to study plant-pollinator interactions. Mol. Ecol. 2021, 1-32, doi:10.1111/mec.16112.

61. Potter, C.; De Vere, N.; Jones, L.E.; Ford, C.R.; Hegarty, M.J.; Hodder, K.H.; Diaz, A.; Franklin, E.L. Pollen metabarcoding reveals broad and species-specific resource use by urban bees. PeerJ 2019, 2019, 1-22, doi:10.7717/peerj.5999.

62. Goulson, D.; Hanley, M.E.; Darvill, B.; Ellis, J.S.; Knight, M.E. Causes of rarity in bumblebees. Biol. Conserv. 2005, 122, 1-8, doi:10.1016/j.biocon.2004.06.017.

63. Falk, S.J.; Lewington, R. Field Guide to the Bees of Great Britain and Ireland; 1st ed.; British Wildlife Publishing, BLOOMSBURY, 2015;

64. Robinson, S.V.J.; Losapio, G.; Henry, G.H.R. Flower-power: Flower diversity is a stronger predictor of network structure than insect diversity in an Arctic plant-pollinator network. Ecol. Complex. 2018, 36, 1-6, doi:10.1016/j.ecocom.2018.04.005.

65. Hebert, P.D.N.; Cywinska, A.; Ball, S.L.; deWaard, J.R. Biological identifications through DNA barcodes. Proc. R. Soc. B Biol. Sci. 2003, 270, 313-321, doi:10.1098/rspb.2002.2218.

66. Pornon, A.; Baksay, S.; Escaravage, N.; Burrus, M.; Andalo, C. Pollinator specialization increases with a decrease in a massflowering plant in networks inferred from DNA metabarcoding. Ecol. Evol. 2019, 9, 13650-13662, doi:10.1002/ece3.5531.

67. Bosch, J.; Martín González, A.M.; Rodrigo, A.; Navarro, D. Plant-pollinator networks: Adding the pollinator's perspective. Ecol. Lett. 2009, 12, 409-419, doi:10.1111/j.1461-0248.2009.01296.x.

68. Lucas, A.; Bodger, O.; Brosi, B.J.; Ford, C.R.; Forman, D.W.; Greig, C.; Hegarty, M.; Jones, L.; Neyland, P.J.; de Vere, N. Floral resource partitioning by individuals within generalised hoverfly pollination networks revealed by DNA metabarcoding. Sci. Rep. 2018, 8, 5133, doi:10.1038/s41598-018-23103-0. 
69. Richardson, R.T.; Lin, C.-H.; Sponsler, D.B.; Quijia, J.O.; Goodell, K.; Johnson, R.M. Application of ITS2 Metabarcoding to Determine the Provenance of Pollen Collected by Honey Bees in an Agroecosystem. Appl. Plant Sci. 2015, 3, 1400066, doi:10.3732/apps.1400066.

70. Smart, M.D.; Cornman, R.S.; Iwanowicz, D.D.; McDermott-Kubeczko, M.; Pettis, J.S.; Spivak, M.S.; Otto, C.R.V. A comparison of honey bee-collected pollen from working agricultural lands using light microscopy and its metabarcoding. Environ. Entomol. 2017, 46, 38-49, doi:10.1093/ee/nvw159.

71. Keller, A.; Danner, N.; Grimmer, G.; Ankenbrand, M.; von der Ohe, K.; von der Ohe, W.; Rost, S.; Hartel, S.; Steffan-Dewenter, I. Evaluating multiplexed next-generation sequencing as a method in palynology for mixed pollen samples. Plant Biol. 2015, 17, 558-566, doi:10.1111/plb.12251.

72. Hawkins, J.; De Vere, N.; Griffith, A.; Ford, C.R.; Allainguillaume, J.; Hegarty, M.J.; Baillie, L.; Adams-Groom, B. Using DNA metabarcoding to identify the floral composition of honey: A new tool for investigating honey bee foraging preferences. PLoS One 2015, 10, 1-20, doi:10.1371/journal.pone.0134735.

73. Richardson, R.T.; Lin, C.; Quijia, J.O.; Riusech, N.S.; Goodell, K.; Johnson, R.M. Rank-based characterization of pollen assemblages collected by honey bees using a multi-locus metabarcoding approach. Appl. Plant Sci. 2015, 3, 1500043, doi:10.3732/apps.1500043.

74. Bell, K.L.; Fowler, J.; Burgess, K.S.; Dobbs, E.K.; Gruenewald, D.; Lawley, B.; Morozumi, C.; Brosi, B.J. Applying Pollen DNA Metabarcoding to the Study of Plant-Pollinator Interactions. Appl. Plant Sci. 2017, 5, 1600124, doi:10.3732/apps.1600124.

75. Sickel, W.; Ankenbrand, M.J.; Grimmer, G.; Holzschuh, A.; Härtel, S.; Lanzen, J.; Steffan-Dewenter, I.; Keller, A. Increased efficiency in identifying mixed pollen samples by meta-barcoding with a dual-indexing approach. BMC Ecol. 2015, 15, 20, doi:10.1186/s12898-015-0051-y.

76. Deagle, B.E.; Thomas, A.C.; McInnes, J.C.; Clarke, L.J.; Vesterinen, E.J.; Clare, E.L.; Kartzinel, T.R.; Eveson, J.P. Counting with DNA in metabarcoding studies: How should we convert sequence reads to dietary data? Mol. Ecol. 2019, 28, 391-406, doi:10.1111/mec.14734.

77. Lu, H.; Dou, F.; Hao, Y.; Li, Y.; Zhang, K.; Zhang, H.; Zhou, Z.; Zhu, C.; Huang, D.; Luo, A. Metabarcoding Analysis of Pollen Species Foraged by Osmia excavata Alfken (Hymenoptera: Megachilidae) in China. Front. Ecol. Evol. 2021, 9, doi:10.3389/fevo.2021.730549.

78. Gous, A.; Swanevelder, D.Z.H.; Eardley, C.D.; Willows-Munro, S. Plant-pollinator interactions over time: Pollen metabarcoding from bees in a historic collection. Evol. Appl. 2019, 12, 187-197, doi:10.1111/eva.12707.

79. Polling, M.; ter Schure, A.T.M.; van Geel, B.; van Bokhoven, T.; Boessenkool, S.; MacKay, G.; Langeveld, B.W.; Ariza, M.; van der Plicht, H.; Protopopov, A. V.; et al. Multiproxy analysis of permafrost preserved faeces provides an unprecedented insight into the diets and habitats of extinct and extant megafauna. Quat. Sci. Rev. 2021, 267, 107084, doi:10.1016/j.quascirev.2021.107084.

80. Danner, N.; Keller, A.; Härtel, S.; Steffan-Dewenter, I. Honey bee foraging ecology: Season but not landscape diversity shapes the amount and diversity of collected pollen. PLoS One 2017, 12, 9-12, doi:10.1371/journal.pone.0183716.

81. Park, B.; Nieh, J.C. Seasonal trends in honey bee pollen foraging revealed through DNA barcoding of bee-collected pollen. Insectes Soc. 2017, 64, 425-437, doi:10.1007/s00040-017-0565-8.

82. Gous, A.; Eardley, C.D.; Johnson, S.D.; Swanevelder, D.Z.H.; Willows-Munro, S. Floral hosts of leaf-cutter bees (Megachilidae) in a biodiversity hotspot revealed by pollen DNA metabarcoding of historic specimens. PLoS One 2021, 16, 1-16, doi:10.1371/journal.pone.0244973.

83. Simanonok, M.P.; Otto, C.R.V.; Cornman, R.S.; Iwanowicz, D.D.; Strange, J.P.; Smith, T.A. A century of pollen foraging by the endangered rusty patched bumble bee (Bombus affinis): inferences from molecular sequencing of museum specimens. Biodivers. Conserv. 2021, 30, 123-137, doi:10.1007/s10531-020-02081-8.

84. Suchan, T.; Talavera, G.; Sáez, L.; Ronikier, M.; Vila, R. Pollen metabarcoding as a tool for tracking long-distance insect migrations. Mol. Ecol. Resour. 2018, doi:10.1111/1755-0998.12948.

85. Kratschmer, S.; Petrović, B.; Curto, M.; Meimberg, H.; Pachinger, B. Pollen availability for the Horned mason bee (Osmia cornuta) in regions of different land use and landscape structures. Ecol. Entomol. 2020, 45, 525-537, doi:10.1111/een.12823.

86. Hicks, D.M.; Ouvrard, P.; Baldock, K.C.R.; Baude, M.; Goddard, M. a.; Kunin, W.E.; Mitschunas, N.; Memmott, J.; Morse, H.; Nikolitsi, M.; et al. Food for pollinators: Quantifying the nectar and pollen resources of urban flower meadows. PLoS One 2016, 11, 1-37, doi:10.1371/journal.pone.0158117.

87. Hegland, S.J.; Boeke, L. Relationships between the density and diversity of floral resources and flower visitor activity in a temperate grassland community. Ecol. Entomol. 2006, 31, 532-538, doi:10.1111/j.1365-2311.2006.00812.x.

88. Fowler, R.E.; Rotheray, E.L.; Goulson, D. Floral abundance and resource quality influence pollinator choice. Insect Conserv. Divers. 2016, 9, 481-494, doi:10.1111/icad.12197.

89. Timberlake, T.P.; Vaughan, I.P.; Memmott, J. Phenology of farmland floral resources reveals seasonal gaps in nectar availability for bumblebees. J. Appl. Ecol. 2019, 1585-1596, doi:10.1111/1365-2664.13403.

90. Richardson, R.T.; Eaton, T.D.; Lin, C.H.; Cherry, G.; Johnson, R.M.; Sponsler, D.B. Application of plant metabarcoding to identify diverse honeybee pollen forage along an urban-agricultural gradient. Mol. Ecol. 2021, 30, 310-323, doi:10.1111/mec.15704.

91. Timberlake, T. Mind the Gap: The importance of flowering phenology in pollinator conservation. Dr. Diss. Univ. Bristol 2019.

92. Jones, L. Investigating the foraging preferences of the honeybee, Apis mellifera L., using DNA metabarcoding, 2020.

93. Nürnberger, F.; Keller, A.; Härtel, S.; Steffan-Dewenter, I. Honey bee waggle dance communication increases diversity of pollen diets in intensively managed agricultural landscapes. Mol. Ecol. 2019, 28, 3602-3611, doi:10.1111/mec.15156. 
94. Quinlan, G.; Milbrath, M.; Otto, C.; Smart, A.; Iwanowicz, D.; Cornman, R.S.; Isaacs, R. Honey bee foraged pollen reveals temporal changes in pollen protein content and changes in forager choice for abundant versus high protein flowers. Agric. Ecosyst. Environ. 2021, 322, 107645, doi:10.1016/j.agee.2021.107645.

95. Bontšutšnaja, A.; Karise, R.; Mänd, M.; Smagghe, G. Bumble bee foraged pollen analyses in spring time in southern estonia shows abundant food sources. Insects 2021, 12, 1-15, doi:10.3390/insects12100922.

96. Casanelles-Abella, J.; Müller, S.; Keller, A.; Aleixo, C.; Alós Orti, M.; Chiron, F.; Deguines, N.; Hallikma, T.; Laanisto, L.; Pinho, P.; et al. How wild bees find a way in European cities: Pollen metabarcoding unravels multiple feeding strategies and their effects on distribution patterns in four wild bee species. J. Appl. Ecol. 2021, 1-14, doi:10.1111/1365-2664.14063.

97. Simanonok, M.P.; Otto, C.R. V.; Iwanowicz, D.D.; Cornman, R.S. Honey bee-collected pollen richness and protein content across an agricultural land-use gradient. Apidologie 2021, doi:10.1007/s13592-021-00902-5.

98. Tommasi, N.; Biella, P.; Guzzetti, L.; Lasway, J.V.; Njovu, H.K.; Tapparo, A.; Agostinetto, G.; Peters, M.K.; Steffan-Dewenter, I.; Labra, M.; et al. Impact of land use intensification and local features on plants and pollinators in Sub-Saharan smallholder farms. Agric. Ecosyst. Environ. 2021, 319, 107560, doi:10.1016/j.agee.2021.107560.

99. Wilson, R.S.; Keller, A.; Shapcott, A.; Leonhardt, S.D.; Sickel, W.; Hardwick, J.L.; Heard, T.A.; Kaluza, B.F.; Wallace, H.M. Many small rather than few large sources identified in long-term bee pollen diets in agroecosystems. Agric. Ecosyst. Environ. 2021, 310, 107296, doi:10.1016/j.agee.2020.107296.

100. Evans, D.M.; Kitson, J.J.N.; Lunt, D.H.; Straw, N.A.; Pocock, M.J.O. Merging DNA metabarcoding and ecological network analysis to understand and build resilient terrestrial ecosystems. Funct. Ecol. 2016, 30, 1904-1916, doi:10.1111/1365-2435.12659.

101. Biesmeijer, J.C.; Roberts, S.P.M.; Reemer, M.; Ohlemuller, R.; Edwards, M.; Peeters, T.; Schaffers, A.P.; Potts, S.G.; Kleukers, R.; Thoimas, C.D.; et al. Parallel Declines in Pollinators and Insect-Pollinated Plants in Britain and the Netherlands. Science (80-. ). 2006, 313, 351-354, doi:10.1126/science.1127863.

102. Memmott, J.; Waser, N.M.; Price, M. V. Tolerance of pollination networks to species extinctions. Proc. R. Soc. B Biol. Sci. 2004, 271, 2605-2611, doi:10.1098/rspb.2004.2909.

103. Elliott, B.; Wilson, R.; Shapcott, A.; Keller, A.; Newis, R.; Cannizzaro, C.; Burwell, C.; Smith, T.; Leonhardt, S.D.; Kämper, W.; et al. Pollen diets and niche overlap of honey bees and native bees in protected areas. Basic Appl. Ecol. 2021, 50, 169-180, doi:10.1016/j.baae.2020.12.002.

104. Brosi, B.J. Pollinator specialization: From the individual to the community. New Phytol. 2016, 210, 1190-1194, doi:10.1111/nph.13951.

105. Klečka, J.; Mikát, M.; Koloušková, P.; Hadrava, J.; Straka, J. Individual-level specialisation and interspecific resource partitioning in bees revealed by pollen DNA metabarcoding. bioRxiv 2021, doi:10.1101/2021.08.01.454648.

106. Kaluza, B.F.; Wallace, H.M.; Heard, T.A.; Minden, V.; Klein, A.; Leonhardt, S.D. Social bees are fitter in more biodiverse environments. Sci. Rep. 2018, 8, 1-10, doi:10.1038/s41598-018-30126-0.

107. Donkersley, P.; Rhodes, G.; Pickup, R.W.; Jones, K.C.; Power, E.F.; Wright, G.A.; Wilson, K. Nutritional composition of honey bee food stores vary with floral composition. Oecologia 2017, 185, 749-761, doi:10.1007/s00442-017-3968-3.

108. Trinkl, M.; Kaluza, B.F.; Wallace, H.; Heard, T.A.; Keller, A.; Leonhardt, S.D. Floral species richness correlates with changes in the nutritional quality of larval diets in a stingless bee. Insects 2020, 11, 1-19, doi:10.3390/insects11020125.

109. Dew, R.M.; McFrederick, Q.S.; Rehan, S.M. Diverse diets with consistent core microbiome in wild bee pollen provisions. Insects 2020, 11, 1-12, doi:10.3390/insects11080499.

110. McFrederick, Q.S.; Rehan, S.M. Characterization of pollen and bacterial community composition in brood provisions of a small carpenter bee. Mol. Ecol. 2016, 25, 2302-2311, doi:10.1111/mec.13608.

111. McFrederick, Q.S.; Rehan, S.M. Wild Bee Pollen Usage and Microbial Communities Co-vary Across Landscapes. Microb. Ecol. 2019, 77, 513-522, doi:10.1007/s00248-018-1232-y.

112. Voulgari-Kokota, A.; Ankenbrand, M.J.; Grimmer, G.; Steffan-Dewenter, I.; Keller, A. Linking pollen foraging of megachilid bees to their nest bacterial microbiota. Ecol. Evol. 2019, 9, 10788-10800, doi:10.1002/ece3.5599.

113. Piot, N.; Eeraerts, M.; Pisman, M.; Claus, G.; Meeus, I.; Smagghe, G. More is less: mass-flowering fruit tree crops dilute parasite transmission between bees. Int. J. Parasitol. 2021, 51, 777-785, doi:10.1016/j.ijpara.2021.02.002.

114. Cullen, N.; Xia, J.; Wei, N.; Kaczorowski, R.; Arceo-Gómez, G.; O’Neill, E.; Hayes, R.; Ashman, T.-L. Diversity and composition of pollen loads carried by pollinators are primarily driven by insect traits, not floral community characteristics. Oecologia 2021, 196, 131-143, doi:10.1007/s00442-021-04911-0.

115. Stout, J.C.; Kells, A.R.; Goulson, D. Pollination of the invasive exotic shrub Lupinus arboreus (Fabaceae) by introduced bees in Tasmania. Biol. Conserv. 2002, 106, 425-434, doi:10.1016/S0006-3207(02)00046-0.

116. Willmer, P.G. The effects of insect visitors on nectar constituents in temperate plants. Oecologia 1980, 47, 270-277, doi:10.1007/BF00346832.

117. Ballantyne, G.; Baldock, K.C.R.; Willmer, P.G. Constructing more informative plantpollinator networks: Visitation and pollen deposition networks in a heathland plant community. Proc. R. Soc. B Biol. Sci. 2015, 282, doi:10.1098/rspb.2015.1130.

118. Tommasi, N.; Ferrari, A.; Labra, M.; Galimberti, A.; Biella, P. Harnessing the Power of Metabarcoding in the Ecological Interpretation of Plant-Pollinator DNA Data: Strategies and Consequences of Filtering Approaches. Diversity 2021, 13, 437, doi:10.3390/d13090437.

119. Tanaka, K.; Nozaki, A.; Nakadai, H.; Shiwa, Y.; Shimizu-Kadota, M. Using pollen DNA metabarcoding to profile nectar sources of urban beekeeping in Kōtō-ku, Tokyo. BMC Res. Notes 2020, 13, 1-6, doi:10.1186/s13104-020-05361-2. 
120. Bertrand, C.; Eckerter, P.W.; Ammann, L.; Entling, M.H.; Gobet, E.; Herzog, F.; Mestre, L.; Tinner, W.; Albrecht, M. Seasonal shifts and complementary use of pollen sources by two bees, a lacewing and a ladybeetle species in European agricultural landscapes. J. Appl. Ecol. 2019, 56, 2431-2442, doi:10.1111/1365-2664.13483.

121. Rotheray, G.E.; Gilbert, F. The Natural History of Hoverflies; Forrest Text: Ceredigion, 2011;

122. Liu, M.; Clarke, L.J.; Baker, S.C.; Jordan, G.J.; Burridge, C.P. A practical guide to DNA metabarcoding for entomological ecologists. Ecol. Entomol. 2020, 45, 373-385, doi:10.1111/een.12831.

123. Quaresma, A.; Brodschneider, R.; Gratzer, K.; Gray, A.; Keller, A.; Kilpinen, O.; Rufino, J.; van der Steen, J.; Vejsnæs, F.; Pinto, M.A. Preservation methods of honey bee-collected pollen are not a source of bias in ITS2 metabarcoding. Environ. Monit. Assess. 2021, 193, 1-20, doi:10.1007/s10661-021-09563-4.

124. Abdel-Latif, A.; Osman, G. Comparison of three genomic DNA extraction methods to obtain high DNA quality from maize. Plant Methods 2017, 13, 1-9, doi:10.1186/s13007-016-0152-4.

125. Swenson, S.J.; Gemeinholzer, B. Testing the effect of pollen exine rupture on metabarcoding with Illumina sequencing. PLoS One 2021, 16, 1-16, doi:10.1371/journal.pone.0245611.

126. Jones, L.; Twyford, A.D.; Ford, C.R.; Rich, T.C.G.; Davies, H.; Forrest, L.L.; Hart, M.L.; McHaffie, H.; Brown, M.R.; Hollingsworth, P.M.; et al. Barcode UK: A complete DNA barcoding resource for the flowering plants and conifers of the United Kingdom. Mol. Ecol. Resour. 2021, 1755-0998.13388, doi:10.1111/1755-0998.13388.

127. Hollingsworth, P.M.; Graham, S.W.; Little, D.P. Choosing and using a plant DNA barcode. PLoS One 2011, 6, doi:10.1371/journal.pone.0019254.

128. Richardson, R.T.; Curtis, H.R.; Matcham, E.G.; Lin, C.H.; Suresh, S.; Sponsler, D.B.; Hearon, L.E.; Johnson, R.M. Quantitative multi-locus metabarcoding and waggle dance interpretation reveal honey bee spring foraging patterns in Midwest agroecosystems. Mol. Ecol. 2019, 28, 686-697, doi:10.1111/mec.14975.

129. Brennan, G.L.; Potter, C.; de Vere, N.; Griffith, G.W.; Skjøth, C.A.; Osborne, N.J.; Wheeler, B.W.; McInnes, R.N.; Clewlow, Y.; Barber, A.; et al. Temperate airborne grass pollen defined by spatio-temporal shifts in community composition. Nat. Ecol. Evol. 2019, 3, 750-754, doi:10.1038/s41559-019-0849-7.

130. Bohmann, K.; Elbrecht, V.; Carøe, C.; Bista, I.; Leese, F.; Bunce, M.; Yu, D.W.; Seymour, M.; Dumbrell, A.J.; Creer, S. Strategies for sample labelling and library preparation in DNA metabarcoding studies. Mol. Ecol. Resour. 2021, 1-18, doi:10.1111/17550998.13512.

131. Geiger, M.; Moriniere, J.; Hausmann, A.; Haszprunar, G.; Wägele, W.; Hebert, P.; Rulik, B. Testing the Global Malaise Trap Program - How well does the current barcode reference library identify flying insects in Germany? Biodivers. Data J. 2016, 4, e10671, doi:10.3897/BDJ.4.e10671.

132. de Vere, N.; Rich, T.C.G.; Ford, C.R.; Trinder, S.A.; Long, C.; Moore, C.W.; Satterthwaite, D.; Davies, H.; Allainguillaume, J.; Ronca, S.; et al. DNA barcoding the native flowering plants and conifers of wales. PLoS One 2012, 7, 1-12, doi:10.1371/journal.pone.0037945.

133. Kuzmina, M.L.; Braukmann, T.W.A.; Fazekas, A.J.; Graham, S.W.; Dewaard, S.L.; Rodrigues, A.; Bennett, B.A.; Dickinson, T.A.; Saarela, J.M.; Catling, P.M.; et al. Using Herbarium-Derived DNAs to Assemble a Large-Scale DNA Barcode Library for the Vascular Plants of Canada. Appl. Plant Sci. 2017, 5, 1700079, doi:10.3732/apps.1700079.

134. Alsos, I.G.; Lavergne, S.; Merkel, M.K.F.; Boleda, M.; Lammers, Y.; Alberti, A.; Pouchon, C.; Denoeud, F.; Pitelkova, I.; Pușcaş, M.; et al. The treasure vault can be opened: Large-scale genome skimming works well using herbarium and silica gel dried material. Plants 2020, 9, doi:10.3390/plants9040432.

135. Kress, W.J. Plant DNA barcodes: Applications today and in the future. J. Syst. Evol. 2017, 55, 291-307, doi:10.1111/jse.12254.

136. Biella, P.; Tommasi, N.; Akter, A.; Guzzetti, L.; Klečka, J.; Sandionigi, A.; Labra, M.; Galimberti, A. Foraging strategies are maintained despite workforce reduction: A multidisciplinary survey on the pollen collected by a social pollinator. PLoS One 2019, 14, e0224037, doi:10.1371/journal.pone.0224037.

137. Cornman, R.S.; Otto, C.R.V.; Iwanowicz, D.; Pettis, J.S. Taxonomic characterization of honey bee (Apis mellifera) pollen foraging based on non-overlapping paired-end sequencing of nuclear ribosomal loci. PLoS One 2015, 10, 1-26, doi:10.1371/journal.pone.0145365.

138. Harris, D.J. Can you bank on GenBank? Trends Ecol. Evol. 2003, 18, 317-319, doi:10.1016/S0169-5347(03)00150-2.

139. Bell, K.L.; Burgess, K.S.; Botsch, J.C.; Dobbs, E.K.; Read, T.D.; Brosi, B.J. Quantitative and qualitative assessment of pollen DNA metabarcoding using constructed species mixtures. Mol. Ecol. 2019, 28, 431-455, doi:10.1111/mec.14840.

140. Polling, M.; Sin, M.; de Weger, L.A.; Speksnijder, A.G.C.L.; Koenders, M.J.F.; de Boer, H.; Gravendeel, B. DNA metabarcoding using nrITS2 provides highly qualitative and quantitative results for airborne pollen monitoring. Sci. Total Environ. 2022, 806, 150468, doi:10.1016/j.scitotenv.2021.150468.

141. Baksay, S.; Pornon, A.; Burrus, M.; Mariette, J.; Andalo, C.; Escaravage, N. Experimental quantification of pollen with DNA metabarcoding using ITS1 and trnL. Sci. Rep. 2020, 10, 1-9, doi:10.1038/s41598-020-61198-6.

142. Lamb, P.D.; Hunter, E.; Pinnegar, J.K.; Creer, S.; Davies, R.G.; Taylor, M.I. How quantitative is metabarcoding: A meta-analytical approach. Mol. Ecol. 2019, 28, 420-430, doi:10.1111/mec.14920.

143. Piñol, J.; Senar, M.A.; Symondson, W.O.C. The choice of universal primers and the characteristics of the species mixture determine when DNA metabarcoding can be quantitative. Mol. Ecol. 2019, 28, 407-419, doi:10.1111/mec.14776.

144. Bänsch, S.; Tscharntke, T.; Ratnieks, F.L.W.; Härtel, S.; Westphal, C. Foraging of honey bees in agricultural landscapes with changing patterns of flower resources. Agric. Ecosyst. Environ. 2020, 291, 106792, doi:10.1016/j.agee.2019.106792.

145. Chui, S.X.; Keller, A.; Leonhardt, S.D. Functional resin use in solitary bees. Ecol. Entomol. 2021, 1-22, doi:10.1111/een.13103. 
146. Deiner, K.; Bik, H.M.; Mächler, E.; Seymour, M.; Lacoursière-Roussel, A.; Altermatt, F.; Creer, S.; Bista, I.; Lodge, D.M.; de Vere, N.; et al. Environmental DNA metabarcoding: Transforming how we survey animal and plant communities. Mol. Ecol. 2017, 5872-5895, doi:10.1111/mec.14350.

147. Bohmann, K.; Mirarab, S.; Bafna, V.; Gilbert, M.T.P. Beyond DNA barcoding: The unrealized potential of genome skim data in sample identification. Mol. Ecol. 2020, 2521-2534, doi:10.1111/mec.15507.

148. Chiou, S. J., Yen, J. H., Fang, C. L., Chen, H. L., \& Lin, T. Y. (2007). Authentication of medicinal herbs using PCR-amplified ITS2 with specific primers. Planta Medica, 73(13), 1421-1426. https://doi.org/10.1055/s-2007-990227

149. de Vere, N., Rich, T. C. G., Ford, C. R., Trinder, S. A., Long, C., Moore, C. W., ... Wilkinson, M. J. (2012). DNA barcoding the native flowering plants and conifers of wales. PLoS ONE, 7(6), 1-12. https://doi.org/10.1371/journal.pone.0037945

150. Kress, W. J., \& Erickson, D. L. (2007). A Two-Locus Global DNA Barcode for Land Plants: The Coding rbcL Gene Complements the Non-Coding trnH-psbA Spacer Region. PLoS ONE, 2(6). https://doi.org/10.1371/journal.pone.0000508

151. Moorhouse-Gann, R. J., Dunn, J. C., De Vere, N., Goder, M., Cole, N., Hipperson, H., \& Symondson, W. O. C. (2018). New universal ITS2 primers for high-resolution herbivory analyses using DNA metabarcoding in both tropical and temperate zones. Scientific Reports, 8(1), 1-15. https://doi.org/10.1038/s41598-018-26648-2 